\title{
PHYSICO-CHEMICAL STANDARDIZATION OF A UNANI ANALGESIC FORMULATION HABB-E-SURANJAN
}

\author{
Shahid Suhail ${ }^{1}$, Shagufta Parveen ${ }^{*}$, Shazia Jilani' ${ }^{3}$, Shama ${ }^{4}$ \\ ${ }^{1}$ Assistant Professor, Department of Moalajat, Deoband Unani Medical College, Hospital and Research Centre, Deoband. \\ 2 Research Associate, Central Council for Research in Unani Medicine, Ministry of AYUSH, New Delhi \\ ${ }^{3}$ Assistant Professor Department of Moalajat, School of Unani Medical Education and Research, Jamia Hamdard. \\ ${ }^{4}$ Associate Professor Department of Ilmul Atfal, Glocal College of Unani Medical Science and Research Centre, Saharanpur.
}

\begin{abstract}
Habb-e-Suranjaan is an important compound preparation which is used for a centuries in Unani system of medicine as an effective analgesic for all types of Waj-al-Mafasil (Arthritics). The drug is known for its pharmacological actions such as Mushile-Balgham (Phlegmagogue), MushileSafra (Cholagogue), Mushile-Sauda (Melanagogue), Mohallile-Waram (Anti-inflammatory), Musakkin-e-Alam (Analgesic), Dafae Niqris (Antigout) Muqawwi-e asaab (Nervine tonic) Munawwim (Hypnotic/Soporific), Musaffi-e-Dam (Blood Purifier). Ingredients of Habb-e-Suranjaan play very effective role in management of different types of Waj-al-Mafasil. In this article, standardized value of a specimen of Habb-e Suranjaan assessed on physico-chemical and analytical parameters viz Macroscopic and microscopic features, extractive values, moisture contents, Ash values, loss of weight on drying, pH of $1 \%$ and $10 \%$ solution, TLC and Fluorescence analysis are provided. The moisture content and the ash value were found within the recommended normal range. The value of different hot extracts (Petroleum ether, Methanol, chlorof orm and Aqueous) is more than the cold extracts of drug.
\end{abstract}

Keywords- Habb-e-Suranjaan, Waj-al-Mafasil, Analgesic.

Article Info: Received 11 July 2019; $\quad$ Review Completed 15 August 2019; Accepted 18 August 2019; Available online 30 Aug 2019

Cite this article as:

Suhail S, Parveen S, Jilani S, Shama, PHYSICO-CHEMICAL STANDARDIZATION OF A UNANI ANALGESIC FORMULATION HABB-E-SURANJAN, Journal of Drug Delivery and Therapeutics. 2019; 9(4-A):9-14 http://dx.doi.org/10.22270/jddt.v9i4A.3509

*Address for Correspondence:

Dr. Shagufta Parveen, Research Associate,, Central Council for Research in Unani Medicine, Ministry of AYUSH, New Delhi.

\section{INTRODUCTION}

$H a b b$ (pill) is an ancient dosage form of Unani system of medicine invented by HakeemSeelon 1 . Habb is an Arabic word which means pill but it is used in other meanings also. The constituents of pill may be either one or more than one. It may be prepared either with drugs of the all three origins or two of them or even only one of them. Volume or size of pill may varies, some are very small like size of Sarson (Bressicanigra) seed, Masoor (Lens culinaris)seed, Baajra (Pennissetumglaucum), Matar (Pisumsatvum Linn.) or about to one $\mathrm{cm}$ or more. Pills of one $\mathrm{cm}$ diameter are called Bunduqa (Plural: Banadiq). It is generally similar to size of Reetha fruit (Sapindustrifoliatus) ${ }^{2}, 3$. Habb-e-Suranjaan is an important compound preparation which is used for a long timeinUnani system of medicine as a good analgesic. The compound Habb-e-Suranjanis a Pharmacopoeial formulation mentioned in National Formulary of Unani Medicine and Qarabadeene Majeedi. The ingredients and composition of Habb-e-Suranjan are as follows 4,5 -

\begin{tabular}{|l|l|l|}
\hline Ingredients & Botanical name & Qt. \\
\hline Suranjan Shireen & Colchicum autumnal & $80 \mathrm{~g}$ \\
\hline Turbud & Ipomeaturpethum & $95 \mathrm{~g}$ \\
\hline Aeloa/ Sibr & Aloe barbadensis & $35 \mathrm{~g}$ \\
\hline Habb al-Neel & Ipomeahederacea & $35 \mathrm{~g}$ \\
\hline Gugul / Muqil & Commiphoramukul & $15 \mathrm{~g}$ \\
\hline Mastagi & Pistacialintiscus & $15 \mathrm{~g}$ \\
\hline Tukhm soya /Shibt & Anethumsowa & $35 \mathrm{~g}$ \\
\hline
\end{tabular}

Analgesic property of ingredients of are mentioned in Unani literature in abundance and therapeutic use of compound formulation Habb-e Suranjaan are Waja'-al-Mafasil (Arthralgia), Irq al-Nasa (Sciatica) Niqris(Gout), Falij (Paraplegia), Laqwa (Bell's palsy) as per Unani scholars. $6,7,8,9,10$ 
The drug was purchased from the local market at Khari Baoli, New Delhi, India. The Haboobwas prepared in Saidla Lab, Dept. of Ilmul Advia, School of Unani Medicine, Jamia Hamdard.

Macroscopic and Microscopic features: were recorded.

\section{Morphological Characters}

Detailed study of the morphological character can be helpful in differentiating them from the other habb (pills). The macroscopy of a habb (pills) includes its visual appearance to the naked eye. For each particular morphological group, a particular systemic examination can be carried out. Size, Weight of empty petridish $=\mathrm{w} 1 \mathrm{gm}$

Weight of petridish + test drug $=\mathrm{w} 2 \mathrm{gm}$

Weight of petridish + Dried drug = w3 gm

Weight of Test drug $=(\mathrm{w} 2-\mathrm{w} 1) \mathrm{gm}$

Weight of moisture $=(\mathrm{w} 2-\mathrm{w} 3) \mathrm{gm}$

$\%$ age of moisture w2-w3X 100 w2-w1

\section{Determination of $\mathbf{p H}$}

\section{pH of $1 \%$ solution}

Five gram powder of drug was shaken well and suspended in $100 \mathrm{ml}$ of distilled water. The resulting solution/ mixture were filtered and $\mathrm{pH}$ was measured with a standard glass electrode. Result is summarized in table.

\section{pH of $10 \%$ solution}

\section{Acid Insoluble Ash Content}

$\mathrm{HCl}(2 \mathrm{~N} ; 25 \mathrm{~mL})$ was added to the crucible containing the total ash, covered with a watch glass, and boiled gently for 5 min. The watch glass was rinsed with $5 \mathrm{~mL}$ of hot water and the rinsed contents were added to the crucible. The acid insoluble matter was collected on an ash less filter paper and washed with hot water until the filtrate was neutral. The filter paper containing acid insoluble matter was transferred to the original crucible. The content of crucible incinerated in the furnace at $450 \mathrm{oC}$. The residue was allowed to cool in a desiccator and weighed. The content of the acid insoluble ash (in $\mathrm{mg} / \mathrm{g}$ ) of air-dried material was calculated as follows:

\section{Percentage of acid insoluble ash $=$ WHCl $/$ WDry $\times 100$}

$\mathrm{WHCl}=\mathrm{Wt}$. of $\mathrm{HCl}$ insoluble ash

WDry = Weight of the dried sample

\section{Water soluble ash}

Water $(25 \mathrm{~mL})$ was added to the crucible containing the total ash, covered with a watch glass and boiled gently for $5 \mathrm{~min}$. The watch glass was rinsed with $5 \mathrm{ml}$ of hot water and added to the crucible. The water insoluble matter was collected on an ash less filter paper and washed with hot water. The filter paper containing the water insoluble matter was transferred to the original crucible and incinerated in the muffle furnace at $450^{\circ} \mathrm{C}$.

\section{Percentage of water soluble $a s h=W_{\mathrm{H} 20} / W_{\text {Dry }} \times 100$}

$\mathrm{W}_{\mathrm{H} 2 \mathrm{O}}=\mathrm{Wt}$. of water soluble $\mathrm{ash}=$ Total ash $\mathrm{wt}$. $-\mathrm{wt}$. of water insoluble matter

\section{Hot Extraction of Habb-e-Suranjaan}

$50 \mathrm{~g}$ of coarse powder of the Habb-e-Suranjaan was subjected to extraction with different solvent system like petroleum ether, then chloroform, then ethanol and at last in water through soxhlet apparatus for $6 \mathrm{hr}$. The liquid extracts colour, odour and test are important parts of morphology of a particular habb (pills).

\section{Moisture content (Mc)}

The drug sample $(2 \mathrm{~g})$ was taken in a clean petridish of known weight (w1) and the petridish was weighted along with sample drug (w2). The drug containing Petridish was kept in an oven at 100-1050C for $2 \mathrm{hrs}$ and then the weight (w3) was noted. Then again, the drug with petridish was kept in an oven at 1050C for next $2 \mathrm{hrs}$. The process was repeated until constant weight was obtained. The loss of weight (inmg/g) of air dried was calculated as follows:

The experimentation was performed in the same manner as above taking 10 gof drug instead of $5 \mathrm{~g}$.

\section{Ash value}

The powdered material (5g) was accurately weighed and placed in a crucible. The material was spread in an even layer and it was ignited to a constant weight by gradually increasing the heat to $450{ }^{\circ} \mathrm{C}$ until it was white indicating the absence of carbon. The residual ash was allowed to cool in a desiccator. The content of total ash(in $\mathrm{mg} / \mathrm{g}$ ) of air-dried material was calculated as follows:

\section{Total Ash value}

$\%$ Ash (dry basis) $=W_{\text {Ash }} / W_{\text {Dry }} \times 100$

$\mathrm{W}_{\text {Ash }}=$ Weight of the ashed sample

$\mathrm{W}_{\text {Dry }}=$ Weight of the dried sample

Percentage of total ash $=\mathrm{W}_{\text {Ash }} / \mathrm{W}_{\text {Dry }} \times 100$ thus obtained were put over water bath and evaporated to dryness. The dried extracts were afterward kept for $5 \mathrm{~min}$ in hot oven and their constant successive extractive values were recorded.

\section{Reaction of Habb-e-Suranjan with different reagents}

The test drug was treated with various reagents and color in the test tube was noted.

\section{Thin Layer Chromatography (TLC Profile)}

Chloroform (CHCl3) extract of Habb-e-Suranjan was used for TLC. Chloroform extract was prepared by dissolving $50 \mathrm{~g}$ of Habb-e-Suranjan in $100 \mathrm{ml}$ of Chloroform. Drug solution thereafter filtered and filtrate was concentrated under reduced pressure.

Mobile phase development: Initially, various combination were tried such as chloroform: petroleum ether: ethyl acetate $(2: 2: 1)$, and other solvents in various ratio. Finally upper layer of chloroform: petroleum ether (8:2) was used as mobile phase for Chloroform extract of Habb-eSuranjaan.

\section{RESULTS}

Table-1 Findings of Morphological Characters

\begin{tabular}{|l|l|l|}
\hline S. No. & Parameters & Observation \\
\hline 1. & Size & Round \\
\hline 2. & Color & Light olive brown \\
\hline 3. & Odour & Agreeable \\
\hline 4. & Taste & Astringent. \\
\hline 5. & Appearance & Habb(pills) \\
\hline
\end{tabular}


Table-2 Findings of Physio-chemical Standardization

\begin{tabular}{|c|c|c|}
\hline S. No. & Parameters & (\%) mean \\
\hline 1. & Loss on drying & $2.6 \%$ \\
\hline 2. & Swelling Index & $1.1 \pm 0.10 \%$ \\
\hline \multirow[t]{4}{*}{3.} & Ash values & \\
\hline & Total ash (\%) & $6.4 \%$ \\
\hline & Acid insoluble ash (\%) & $5.2 \%$ \\
\hline & Water soluble ash (\%) & $1.6 \%$ \\
\hline \multirow[t]{3}{*}{4.} & pH & \\
\hline & pH 1\% solution & 6.54 \\
\hline & pH $10 \%$ solution & 5.75 \\
\hline \multirow[t]{5}{*}{5.} & Hot extraction & \\
\hline & Petroleum ether & $4.24 \%$ \\
\hline & Chloroform & $2.04 \%$ \\
\hline & Methanol & $5.6 \%$ \\
\hline & Aqueous & $28.14 \%$ \\
\hline \multirow[t]{5}{*}{6.} & Cold Extraction & \\
\hline & Petroleum ether & $2.5 \%$ \\
\hline & Chloroform & $2.40 \%$ \\
\hline & Methanol & $2.90 \%$ \\
\hline & Aqueous & $22 \%$ \\
\hline \multirow[t]{5}{*}{7.} & Successive Extract Value & \\
\hline & Petroleum ether & $4.15 \%$ \\
\hline & Chloroform & $3.55 \%$ \\
\hline & Methanol & $4.98 \%$ \\
\hline & Aqueous & $12.05 \%$ \\
\hline
\end{tabular}

Table-3 Fluorescence analysis of Habb-e-Suranjan

\begin{tabular}{|c|c|c|c|}
\hline \multirow[t]{2}{*}{ S. No. } & \multirow[b]{2}{*}{ Reagents } & \multicolumn{2}{|c|}{ Observation } \\
\hline & & Day light & $\begin{array}{c}\text { UV light } \\
(254 \mathrm{~nm})\end{array}$ \\
\hline 1. & Powder as such & Light brown & Darkish brown \\
\hline 2. & Powder treated with dist. water & Light brown & Dark brown \\
\hline 3. & Powder treated with Ferric chloride & Dark brown & Blackish brown \\
\hline 4. & Powder treated with Pet. ether & Straw Colour & Yellowish Colour \\
\hline 5. & Powder treated with sodium hydroxide $(\mathrm{NaOH})$ & Light orange & Brown \\
\hline 6. & Powder treated with chloroform $(\mathrm{CHCl} 3)$ & Lemon & Greenish yellow \\
\hline 7. & Powder treated with methanol & Clear & Clear \\
\hline 8. & Powder treated with ethyl acetate & Hazy brown & Yellowish \\
\hline 9. & Powder treated with acetone & Straw Colour & Greenish yellow \\
\hline 10. & Powder treated with hydrochloric acid ( $\mathrm{HCl})$ & Dark brown & Blackish brown \\
\hline 11. & $\begin{array}{l}\text { Powder treated with sulphuric acid } \\
\left(\mathrm{H}_{2} \mathrm{SO}_{4}\right)\end{array}$ & Brick colour & Black colour \\
\hline
\end{tabular}




\section{DISCUSSION AND CONCLUSION}

Morphological characterization of a drug helps in identification of drug as well as detection of adulteration. In some cases, quality of crude drug can be checked on the basis of morphology only. In the present study, it has been observed that test drug had moisture content less than $10 \%$. Low moisture content is always desirable for stability of drug. ${ }^{11}$ High ash values of $6 \%$ suggest presence of inorganic matter. Lower value of the acid insoluble ash suggests the greater physiological availability of drug. Extractive value gives information about availability of soluble phytoconstituents in particular solvent. ${ }^{12}$ Water soluble extractive is more as compared to ethanol, petroleum ether and chloroform extractive value suggesting that aqueous extract

\section{REFERENCES}

1. Husain SF, Ahmad I, Shamsi S. Standardization of the finished product: HabbeIrqunNisa - A Unani anti-inflammatory formulation, Ancient Science of Life. 2012;32(1):38-44

2. Kabir H. Morakkabat (Unani Formulations). Shamsher Publisher and Distributors, Aligarh. 2003; 35.

3. Hamdani MK. Usool-e-Tibb. NCPUL, Ministry of Human Resources Development Govt. Of India New Delhi. 2002; 356-357

4. Anonymous, Qarabadeen-e-Majeedi - Delhi: All India UnaniTibbiConferance, 1986; 85.

5. Anonymous, National Formulary of Unani Medicine,New Delhi : Department of Ayurveda, Yoga \& Naturopathy, Unani, Siddha and Homoeopathy (AYUSH), Ministry of Health \& Family Welfare, Government of India, 2008; Vol. 5 : 6 : pp. 7,17,191-193.

6. Kabeeruddin M. Bayaz-e-Kabeer, Part II. IdaraKitabu-ushShifa, New Delhi. 2010; 50.

7. Jilani G. Makhjan-ul-Ilaaj. IdaraKitabu-ush-Shifa, New Delhi. 2005; 707. would be more beneficial as compared to methanolic extract for therapeutic purposes.

In the light of above finding it may be concluded that test drug Habb-e-Suranjaan is found in good quality on physicchemical parameters as per gold standard.

ACKNOWLEDGMENT: Authors are thankful to Dr.Mohd Asif, Assistant Professor, Department of Ilmul-Advia, Jamia Hamdard, New Delhi, for his valuable suggestion and cooperation during the above study.

CONFLICT OF INTEREST: None declared.

SOURCE OF SUPPORT: Nil

8. Majusi AA. Kamil- us- Sana'ah, Vol. II, (Urdu translation).IdaraKitabu-ush-Shifa,New Delhi. 2010; 505.

9. Arzani A. Qarabadeen-e-Qadri. (Urdu Translation) Central Council for Research in Unani Medicine. Govt. of India, Ministry of Health \& F. W. (Dept. of AYUSH)), New Delhi. 2009; 613-636.

10. Anonymous. National Formulary of Unani Medicine. Part - V. Central Council for Research in Unani Medicine. Govt, of India, Ministry of Health \& F. W. (Dept. of AYUSH)), New Delhi. 2006; 17.

11. Ansari S, Siddiqui MA, Maaz M, Khan QA, Ahmad I. Physiochemical standardization and HPTLC of Artemisia absinthum, Linncollected from KhariBaoli, Delhi. Indo American Journal of Pharmaceutical Research. 2017:7(02);7681-88.

12. Deshpande SG, Kasture VS, Gosavi SA, Bhalke RD, Ajage RK, Inamke SR, Kolpe JB, Jadhav GP. Pharmacognostic Evaluationof Polyherbal Marketed Formulation. International Journal of Pharmacognosy and Phytochemical Research 2014;6 (3): 588-592 